\title{
CULTURAL ADAPTATION AND VALIDATION FOR PORTUGUESE OF THE SPINAL APPEARANCE QUESTIONNAIRE
}

\author{
ADAPTAÇÃO CULTURAL E VALIDAÇÃO DO QUESTIONÁRIO DA APARÊNCIA DA COLUNA \\ VERTEBRAL EM PORTUGUESS
}

\section{ADAPTACIÓN CULTURAL Y VALIDACIÓN EN PORTUGUÉS DEL CUESTIONARIO DE LA APARIENCIA DE LA COLUMNA}

Marcelo Guerra de Albuqueroue Rosendo ${ }^{1}$, Tulio Albuquerque de Moura Rangel ${ }^{1}$, André Flávio Freire Pereira ${ }^{1}$, Marcus André Costa Ferreira', Rodrigo Castro de Medeiros ${ }^{1}$, Luciano Temporal Borges Cabral ${ }^{1}$

1. Hospital Getúlio Vargas, Spine Surgery, Recife, PE, Brazil.

\begin{abstract}
Objective: Make the cultural adaptation of the spinal appearance questionnaire (SAQ). Method: Twenty patients and their accompanying relatives responded to SAC and were asked about possible improvements. Results: Eighteen girls (90\%) and two boys (10\%), average age 14.8 years; Cronbach's alpha values of 0.79 and 0.75 were found for patients and parents respectively. Conclusion: The Brazilian Portuguese version of the spinal appearance questionnaire presented in this paper proves to be a valid tool for their purposes in its pre-trial phase.
\end{abstract}

Keywords: Cross-cultural comparison; Questionnaires; Spine; Scoliosis; Brazil/ethnology.

\section{RESUMO}

Objetivo: Fazer a adaptação cultural do questionário da aparência da coluna (QAC). Método: Vinte pacientes e seus parentes acompanhantes responderam ao QAC e foram questionados quanto a possíveis melhorias. Resultados: Dezoito meninas (90\%) e dois meninos (10\%); média de idade de 14,8 anos; encontrados valores do alfa de Cronbach de 0,79 e 0,75 para pacientes e parentes respectivamente. Conclusão: A versão em português brasileiro do questionário da aparência da coluna vertebral apresentado neste trabalho mostra-se um instrumento válido para os seus fins na sua fase de pré-teste.

Descritores: Comparação transcultural; Questionários; Coluna vertebral; Escoliose; Brasil/etnologia.

\section{RESUMEN}

Objetivo: Hacer la adaptación cultural del cuestionario de la apariencia de la columna (CAC). Método: Veinte pacientes y sus familiares acompañantes respondieron al CAC y se les preguntó acerca de posibles mejoras. Resultados: Dieciocho niñas (90\%) y dos niños (10\%); edad media de 14,8 años; se han encontrado valores alfa de Cronbach de 0,79 y 0,75 para los pacientes y sus familiares, respectivamente. Conclusión: La versión en portugués del cuestionario de la apariencia de la columna presentado en este trabajo, demuestra que es un instrumento válido para sus propósitos en su fase pre-test.

Descriptores: Comparación transcultural; Cuestionarios; Columna vertebral; Escoliosis; Brasil/etnología.

\section{INTRODUCTION}

Idiopathic scoliosis (IS) is a disease without a specific cause that leads to a deviation in the coronal plane of the spine. This deformity occurs in all three dimensions of the spine, causing changes in the appearance of the back of affected patients. ${ }^{1}$ Because this disease has a higher incidence in young girls during puberty, ${ }^{2}$ these deformities can cause problems in the lives of these patients, especially in terms of their mental health and social relationships, making this one of the main challenges in the treatment of these patients. ${ }^{3}$ Despite these problems, the visible deformity caused by the scoliosis is still not taken much into consideration when making decisions about patient treatment.

Over time, several tools have been developed to try to evaluate and quantify several aspects of the quality of life of these patients, and several methods for measuring the perception of the deformity indirectly have also been created. The Walter Reed Visual Evaluation Scale (WRVAS), however, was the first tool to use drawings to specifically evaluate the patient's own perception of their spinal deformity. ${ }^{4}$
Searching for a tool to measure the perception of these deformities with greater precision, Sanders et al. ${ }^{5}$ developed a questionnaire in 2007 aimed at assessing the perceptions of the patients and their relatives regarding several aspects of the appearance of the spinal deformities caused by IS. This questionnaire consists of an illustrated section, inspired by the WRVAS, in which the patient and their family members select the image that best represents the way in which they see the appearance of the deformity at that time and another section with statements to which they try to react, expressing their expectations in terms of the deformity. ${ }^{6}$

Although the questionnaire proposed by Sanders et al. ${ }^{5}$ is a useful tool and has already been validated for monitoring patients with IS, there is neither a validated translation nor a culturally adapted version of this questionnaire for Brazil, creating gaps in a more complete, global evaluation of these patients. This work provides a translation and seeks validation for the use of the Spine Appearance Questionnaire (SAQ) in Brazilian Portuguese, aimed at promoting more widespread use of this tool in Brazil. 


\section{MATERIALS AND METHODS}

The translation and cultural adaptation were conducted following the recommendations of the American Association of Surgery. ${ }^{7}$ The original English versions were translated to Portuguese independently by two orthopedic physicians studying to be spine surgeons, then evaluated together by a committee of five spine surgeons to generate a translated version of each questionnaire. A back translation of each was then done by a native English speaker and this version was compared to the English original. They then made comparisons and published final Portuguese versions of the questionnaires (Figures 1 and 2) for the execution of a pre-test with the target audience.

The data collection took place in the spine surgery clinic of the Hospital Getúlio Vargas (HGV), Recife-PE. The questionnaire was given to patients with IS and their accompanying family members, to be filled out during the outpatient consultations, following an explanation of the purpose of the questionnaire and their acceptance and signing of an informed consent form.

The inclusion criteria adopted were (1) patients 10 years of age or older, (2) with idiopathic scoliosis already submitted to surgery or not. All patients not afflicted by IS or under 10 years of age were excluded from the study, as were those who did not complete the questionnaire or did not agree to participate in the study.

The statistical analysis was performed by an independent statistician using the free $\mathrm{R}$ software, version 3.1.2 for the Linux operating system. The Cronbach's alpha values were calculated to analyze the reliability of the questionnaire.

\section{RESULTS}

A total of 22 patients were approached to fill out the questionnaire.

Instruções: Responda às perguntas preenchendo o círculo correto ou por escrito nas questões. Se você precisar alterar uma reposta, deve apagar completamente a marca incorreta e preencher a marca corretas. Marcar apenas uma resposta para cada pergunta. Por favor, preencher completamente os círculos e não marcar fora dele. Data de hoje (DD/MM/AA)

Por favor, olhe as declarações. Preencha o círculo que melhor descreve a sua condição.

1. Curva do corpo (Marque apenas uma)

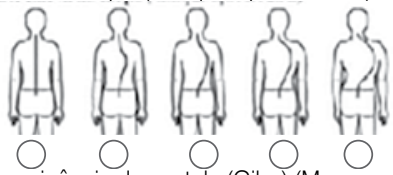

2. Proeminência da costela (Giba) (Marque apenas uma)

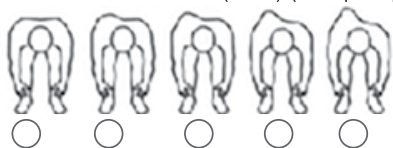

3. Proeminência lombar (Giba) (Maraue apenas uma)

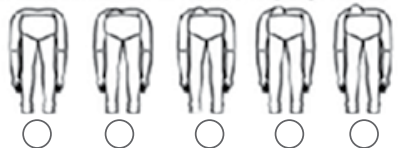

4. Alinhamento cabeça tórax quadril (Marque apenas uma)

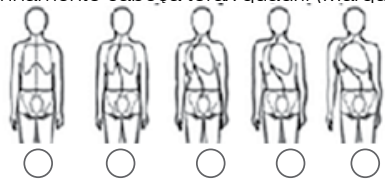

5. Posicão da cabeca sobre o quadril (Marque apenas uma)

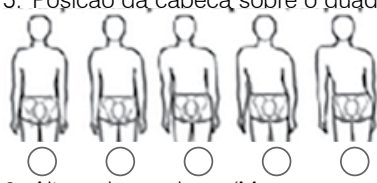

6. Altura dos ombros (Marque apenas uma)

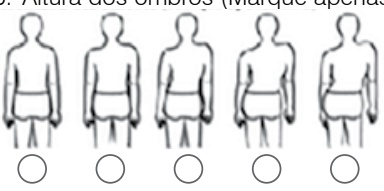

7. Proeminência da coluna (Corcunda) (Marque apenas uma)

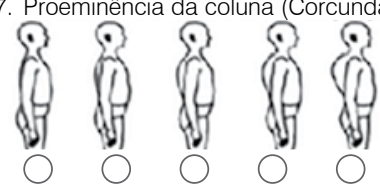

8. Por favor, escolha a categoria que mais the incomoda dentre as 5 imagens abaixo

Proeminência Proeminência Alinhamento cabeça Nível dos Proeminência da costela lombar tórax quadril ombros da coluna
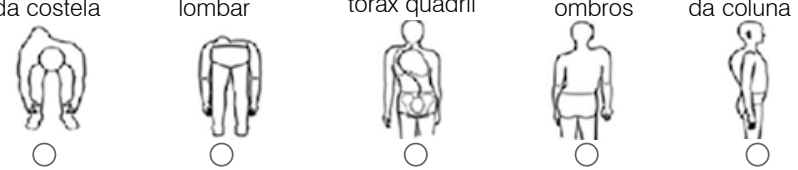

09. Eu quero ser mais reta

10. Eu quero me ver melhor nas roupas

11. Eu quero ter quadris mais nivelados

12. Eu quero ter uma cintura mais modelada

13. Eu quero ter pernas com o mesmo comprimento

14. Eu quero ter seios iguais.

15. Eu quero ter o tórax mais alinhado.

16. Eu quero ter ombro mais alinhado.

17. Eu sou consciente da aparência da cicatriz da minha cirurgia da coluna. (Responda apenas se você foi operado da coluna)

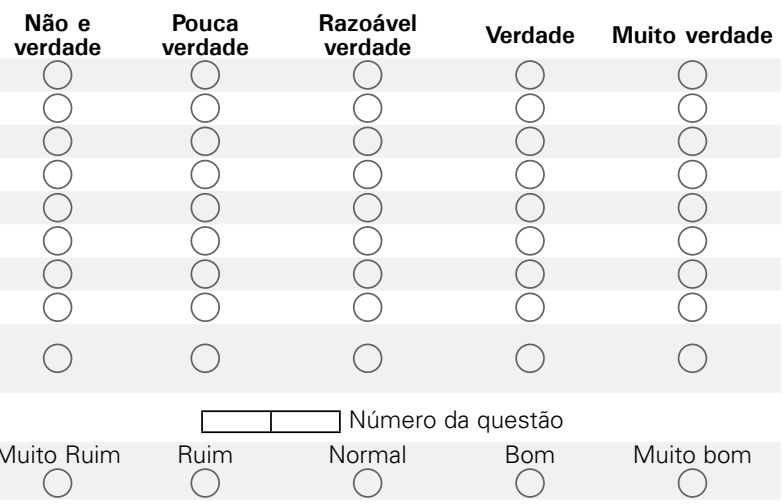

18. Das questões 9 a 17, qual é a mais importante para você?

19. Como você classificaria a sua aparência?

20. O que mais você gostaria de mudar na forma do seu corpo e por quê? 
Instruções: Responda às perguntas preenchendo o cículo correto ou por escrito nas questões. Se você precisar alterar uma resposta, deve apargar completamente a marca incorreta e preencher a marca correta. Marcar apenas uma resposta para cada pergunta. Por favor, preencher completamente os círculos e não marcar fora dele. Data de hoje (DD/MM/AA)

\begin{tabular}{|l|l|l|l|l|}
\hline & $/$ & 1
\end{tabular}

Por favor, olhe com atenção as declarações e ilustrações que descrevem formas da coluna. Preencha o cículo que melhor descreve a condição da sua criança.

1. Curva do corpo (Marque apenas uma)

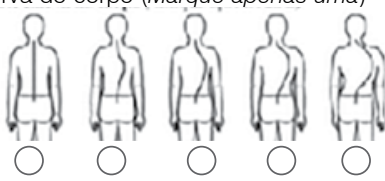

2. Proeminência da costela (Giba) (Marque apenas uma)

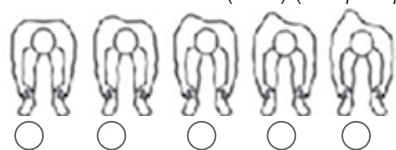

3. Proeminência lombar (Giba) (Maraue apenas uma)

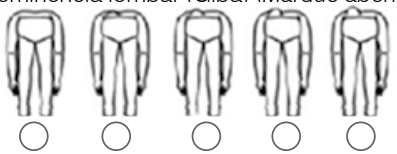

4. Alinhamento cabeca tórax quadril (Marque apenas uma)

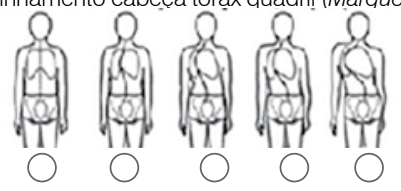

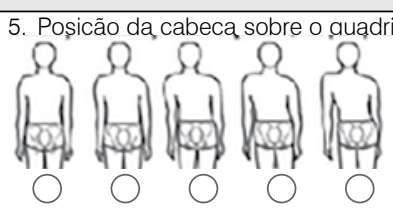

6. Altura dos ombros (Marque apenas uma)

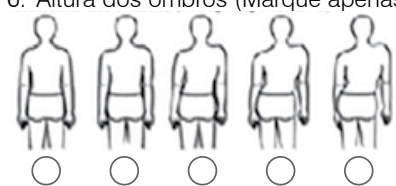

7. Proeminência da coluna (Corçunda) (Marque apenas uma)

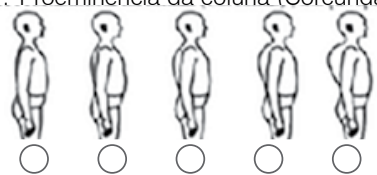

8. Por favor, escolha a categoria que mais the incomoda dentre as 5 imagens abaixo

Proeminência Proeminência Alinhamento cabeça Nível dos Proeminência
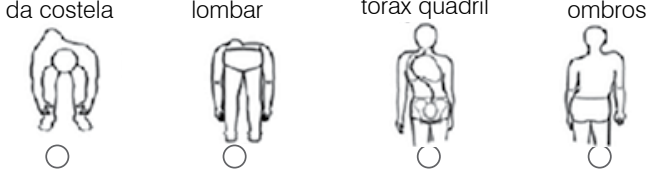

da coluna
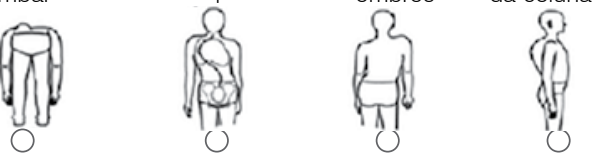

09. Eu quero que minha criança seja mais reta

10. Eu quero me ver minha criança melhor nas roupas

11. Eu quero que minha criança tenha quadris mais alinhados

12. Eu quero que minha criança tenha uma cintura mais modelada

13. Eu quero que minha criança tenha pernas com o mesmo comprimento

14. Eu quero que minha criança tenha seios iguais.

15. Eu quero que minha criança tenha o tórax mais alinhado.

16. Eu quero que minha criança tenha ombro mais alinhado.

17. Eu sou consciente da aparência da cicatriz da minha cirurgia da coluna da minha criança (Responda apenas se você foi operado da coluna)

18. Minha criança é consciente sobre a sua cicatriz da cirurgia na coluna (Responda apenas se você foi operado da coluna)

19. Das questoes 9 a 17, qual é a mais importante para você?

20. Como você classificaria a aparencia da sua criança

21. O que mais você gostaria de mudar na forma do seu corpo da sua criança e por quê?

Figure 2. Spine Appearance Questionnaire in brazilian portuguese.

Of these, one patient refused to complete it saying that her appearance made her so uncomfortable that she did not want to do it, and another patient did not conclude the questionnaire. These two patients were excluded from the study, leaving a total of 20 patients.

Eighteen of the patients were female (90\%) and two were male $(10 \%)$. The average age of the sample population was $14.8( \pm 2.5)$ years. Four (20\%) of these patients had undergone surgery for IS. The average completion times were 6 minutes and 28 seconds and $7 \mathrm{mi}-$ nutes and 44 seconds for the patients and their relatives, respectively.

Reliability was measured using the responses of the patients and their relatives to calculate Cronbach's alpha and yielded values of 0.79 and 0.75 , respectively.

\section{DISCUSSION}

Tools to evaluate patients with IS are very important, given that their lives are affected in different ways and to varying degrees. An understanding of their doubts and concerns about treatment is important for us to better educate patients and make them feel more secure and confident. ${ }^{8}$

In the past, appearance was measured subjectively with 
questionnaires, measurements, and the perceptions of the physician himself, until Walter Reed (WR) launched a new questionnaire to evaluate the perception of the patients directly, with drawings that simulate the patient's appearance in a gradual and staged manner. ${ }^{4}$ Later, Sanders et al., ${ }^{5}$ using the drawings of WR as a reference, designed the SAQ, which sought to assess the perception of the patient and their wishes for their appearance. After several studies, the SAQ has proved to be a statistically valid tool for measuring the perception of the appearance of these paitents. ${ }^{5,6}$

The main objective of this work was to validate the Brazilian Portuguese version of this important tool for the assessment of patients with IS. With this, the final step of the American Association of Surgery protocol ${ }^{7}$ for the translation and cultural adaptation of questionnaires was complete i.e. to show the questionnaire to the target audience, to determine whether there were any difficulties in understanding or executing it, and correct them.

The Cronbach's alpha values of 0.79 for patients and 0.75 for their relatives resulting from our analysis show that the questionnaire is a reliable tool. These values corroborate those found in the literature. ${ }^{5,6,9}$ Analyses of the validation and the internal consistency of the separate domains of the questionnaire were not conducted, nor did we differentiate between patients pre- or postoperatively, or make other clinical and radiological correlations, because the patient sample was small and they were not part of this phase of the questionnaire pre-test

The time it took patients and their relatives to fill out the questionnaire: 6 minutes and 28 seconds and 7 minutes and 44 seconds, respectively, was perfectly acceptable, and the questionnaire was easily completed while the patients waited for their doctor's appointments, in the waiting room.

When questioned about difficulties or suggestions for improvement, most of the patients replied that they completed the questionnaire with no difficulty. The most pertinent observations related to the format, rather than the content of the questionnaire.

\section{CONCLUSION}

The Brazilian Portuguese version of the Spine Appearance Questionnaire presented in this work was shown as a valid tool to achieve its purpose in the pre-test phase. Additional studies are necessary with larger patient samples for a better clinical and statistical validation of the questionnaire.

All the authors declare that there are no conflicts of interest regarding this article.

CONTRIBUTIONS OF THE AUTHORS: Each author made significant individual contributions to the development of this manuscript. TAMR, AFFP, and MACF offered their outpatient clinics and assisted with data collection and patient interviews. TAMR, RCM, and LTBC assisted with the development of the content and the writing of the paper.

\section{REFERENCES}

1. Pineda S, Bago J, Gilperez C, Climent JM. Validity of the Walter Reed Visual Assessment Scale to measure subjective perception of spine deformity in patients with idiopathic scoliosis. Scoliosis. 2006;1:18.

2. Newton $P O, O$ 'Brien MF, Schufflebarger $H L$, Betz RR, Dickson RA, Harms J, editors. Idiopathic scoliosis: the Harms study group treatment guide. New York : Thieme; 2010.

3. Bridwell KH, Shufflebarger HL, Lenke LG, Lowe TG, Betz RR, Bassett GS. Parents' and patients' preferences and concerns in idiopathic adolescent scoliosis: a cross-sectional preoperative analysis. Spine (Phila Pa 1976). 2000;25(18):2392-9

4. Sanders JO, Polly DW Jr, Cats-Baril W, Jones J, Lenke LG, O'Brien MF, et al. Analysis of patient and parent assessment of deformity in idiopathic scoliosis using the Walter Reed Visual Assessment Scale. Spine (Phila Pa 1976). 2003:28(18):2158-63.

5. Sanders JO, Harrast JJ, Kuklo TR, Polly DW, Bridwell KH, Diab M, et al. The Spinal Appearance Questionnaire: results of reliability, validity, and responsiveness testing in patients with idiopathic scoliosis. Spine (Phila Pa 1976). 2007:32(24):2719-22.

6. Carreon LY, Sanders JO, Polly DW, Sucato DJ, Parent S, Roy-Beaudry M, Spinal appearance questionnaire: factor analysis, scoring, reliability, and validity testing. Spine (Phila Pa 1976). 2011;36(18):E1240-4.

7. Beaton DE, Bombardier C, Guillemin F, Ferraz MB. Guidelines for the process of cross-cultural adaptation of self-report measures. Spine (Phila Pa 1976). 2000:25(24):3186-91.

8. Bridwell KH, Shufflebarger HL, Lenke LG, Lowe TG, Betz RR, Bassett GS. Parents' and patients' preferences and concerns in idiopathic adolescente scoliosis: a cross-sectional preoperative analysis. Spine (Phila Pa 1976). 2000;25(18):2392-9.

9. Roy-Beaudry M, Beauséjour M, Joncas J, Forcier M, Bekhiche S, Labelle H, et al. Validation and clinical relevance of a French-Canadian version of the spinal appearance questionnaire in adolescent patients. Spine (Phila Pa 1976). 2011;36(9):746-51 